\title{
THERMOOXIDATIVE REGENERATION OF USED MINERAL MOTOR OILS
}

\author{
Bohdan Korchak ${ }^{1,}$, Oleg Grynyshyn', Taras Chervinskyy1, Pavlo Shapoval ${ }^{1}$, \\ Andriy Nagurskyy ${ }^{1}$
}

https://doi.org/10.23939/chcht14.01.129

\begin{abstract}
The physico-chemical properties and group composition of the used mineral motor oils M-10DM and NORMAL 15W40, as well as the fractions obtained as a result of their thermooxidative regeneration have been studied. The results of IR-spectroscopic and X-ray fluorescence analysis of used oils and fractions obtained during thermooxidative regeneration are presented. The changes in the composition and properties of regenerated oils are described.
\end{abstract}

Keywords: thermooxidative regeneration, used oil, IRspectroscopy.

\section{Introduction}

Used mineral motor oils (UMMO) are toxic, complex, multicomponent systems which are formed during the operation of a combustion engine. More than 140 types of carcinogenic polycyclic hydrocarbons have been identified in UMMO, the number of which increases in direct proportion to the duration of its life cycle $[1,2]$. That is why UMMO are categorized as hazardous waste of the $4^{\text {th }}$ grade of toxicity. The decisions of Stockholm and Basel Conventions [4], which demand control of UMMO formation and utilization, are in force in the world, including Ukraine. According to [3] the production of hazardous wastes should be minimized, adequate disposal plants should be installed, and eco-friendly utilization of waste containing hazardous carcinogens should be provided.

Today in Ukraine about $1 \mathrm{mln}$. tons per year of fresh oils are consumed and about 500,000 tons per year of used oils are officially collected. Such considerable bulk of UMMO is one of the most acute environmental problems, arising due to the insufficiently developed collection system and almost undeveloped capacities for their regeneration [4].

\footnotetext{
${ }^{1}$ Lviv Polytechnic National University

12, S.Bandery St., 79013 Lviv, Ukraine

kor4ak93@gmail.com

(C) Korchak B., Grynyshyn O., Chervinskyy T., Shapoval P., Nagurskyy A., 2020
}

It is well-known that the chemical composition of oil during operation changes slightly. Approximately 75$80 \%$ of oil components remain unchanged; the products of oil physico-chemical transformations, as well as impurities which make oils unsuitable for further use, are $\sim 20-25 \%$. Owing to "aging" products removal from UMMO it is possible to obtain oil, the properties of which should correspond to those of fresh oil produced from petroleum raw materials. Therefore, the development of regeneration technology for used oils with a high yield of resulting product and ability to adjust it to domestic refineries without significant upgrading of existing equipment is an urgent problem [5]. The thermooxidative process is one of such methods. In works $[6,7]$ the authors show the possibility of using thermooxidative method to purify diesel and kerosene fractions from sulfur compounds and resins. It would be interesting to know if this method is suitable for the UMMO regeneration.

The essence of the process is to oxidize the primary products of UMMO aging to the formation of condensation products and their extraction using vacuum distillation. Previously [8] we established the optimal parameters of the thermooxidative regeneration for industrial oils, but they are not sufficient to assert that the base oil is produced as a result of UMMO regeneration. Moreover, the change in operational properties for motor oils M-10DM and NORMAL $15 \mathrm{~W} 40$ as well as their group hydrocarbon composition were studied $[9,10]$. The formation of oxygen-containing products of oils "aging" was confirmed during their prolonged use in internal combustion engines and the changes in the composition of inorganic part were observed, which are explained by the action of additives and wear products of the engine. The obtained results can serve as the source information for choosing the optimum technology for used oils regeneration.

So, the purpose of this work was to establish optimal conditions for the thermooxidative regeneration of waste motor oils and to study the characteristics of regenerated oils. 


\section{Experimental}

Used motor oils M-10DM and NORMAL 15W40, removed from the crank case of diesel and gasoline engines, respectively, after the expiration of their operation were the starting materials for researches.

UMMO thermooxidative regeneration was carried out on a laboratory setup consisting of a reactor unit, a system of compression and air purification, cooling and trapping of gaseous reaction products, devices for control and measurement of temperature, pressure, etc. Vacuum separation into fractions was carried out at $623 \mathrm{~K}$ and a residual pressure of $1.07-1.20 \mathrm{kPa}$. The following fractions were obtained: strippant, regenerated oil and residue. The obtained products were studied and analyzed according to standard methods described below.

The density of the samples was determined picnometrically, the refraction index - using a refractometer, viscosity - using a viscosimetry method, flash point in the device of the open type [11]. Group hydrocarbon composition was studied by a chromatography. The silica alumina gel of ASK type was used as an adsorbent. Fractions of hydrocarbons were washed out by petroleum ether and benzene, and asphalt-resinous substances were desorbed by alcohol-benzene mixture.
X-ray fluorescence was used to determine the elemental composition of oils. A mobile precision analyzer EXPERT 3L was used, the assignment of which is to determine the mass fraction of chemical elements in monolithic and homogeneous powder objects [12]. For the analysis we prepared the samples, which were burned at $723 \mathrm{~K}$ for $4 \mathrm{~h}$, cooled in a desiccator and then grinded.

IR spectroscopy was performed on Spectrum Two FT-IR spectrometer (PerkinElmer) using Spectrum v.10.03.06 program. The thickness of the cell made of zinc selenide was $0.1036 \mathrm{~mm}$.

For mathematical modelling of the process Mathcad 15.0 was used [13].

\section{Results and Discussion}

\subsection{Determination of Optimum Parameters}

To determine the optimum parameters of thermooxidative regeneration, a series of experiments was carried out varying temperature, pressure and process time. The experimental results are represented in Table 1.

Table 1

Determination of optimum parameters

\begin{tabular}{|c|c|c|c|c|c|c|c|}
\hline \multirow{2}{*}{\multicolumn{2}{|c|}{ Process parameter }} & \multicolumn{2}{|c|}{ Viscosity, $\mathrm{mm}^{2} / \mathrm{s}$} & \multirow{3}{*}{$\frac{v_{50} / v_{100}}{5.05}$} & \multirow{3}{*}{$\begin{array}{c}\begin{array}{c}\text { Viscosity } \\
\text { index }\end{array} \\
88\end{array}$} & \multirow{3}{*}{$\begin{array}{c}\begin{array}{c}\text { Acid number, } \\
\mathrm{mg} \mathrm{KOH} / \mathrm{g}\end{array} \\
2.71\end{array}$} & \multirow{3}{*}{$\begin{array}{c}\begin{array}{c}\text { Yield, } \\
\text { wt \% }\end{array} \\
-\end{array}$} \\
\hline & & $v_{50}$ & $v_{100}$ & & & & \\
\hline \multirow{4}{*}{ Temperature, $\mathrm{K}^{*}$} & $\begin{array}{c}\text { standard } \\
\text { conditions }\end{array}$ & 51.65 & 10.22 & & & & \\
\hline & 453 & 58.27 & 11.17 & 5.21 & 93 & 2.19 & 78.40 \\
\hline & 473 & 62.05 & 11.67 & 5.30 & 98 & 1.45 & 73.50 \\
\hline & 493 & 63.35 & 12.00 & 5.43 & 100 & 1.28 & 69.94 \\
\hline \multirow{4}{*}{ Time,h** } & $\begin{array}{l}\text { standard } \\
\text { conditions }\end{array}$ & 51.65 & 10.22 & 5.05 & 88 & 2.71 & - \\
\hline & 1.0 & 58.51 & 11.03 & 5.28 & 92 & 1.98 & 78.37 \\
\hline & 2.0 & 61.65 & 11.47 & 5.30 & 98 & 1.62 & 75.34 \\
\hline & 3.0 & 62.05 & 11.67 & 5.32 & 101 & 1.45 & 72.50 \\
\hline \multirow{4}{*}{ Pressure, $\mathrm{MPa}^{* * *}$} & $\begin{array}{c}\text { standard } \\
\text { conditions }\end{array}$ & 51.65 & 10.22 & 5.05 & 88 & 2.71 & - \\
\hline & 1.0 & 59.61 & 10.95 & 5.44 & 94 & 2.11 & 77.95 \\
\hline & 2.0 & 62.05 & 11.67 & 5.32 & 98 & 1.45 & 73.50 \\
\hline & 3.0 & 62.67 & 11.94 & 5.03 & 101 & 1.39 & 70.12 \\
\hline
\end{tabular}

Notes: * process time is $2.0 \mathrm{~h}$, pressure is $2 \mathrm{MPa}$; ** temperature is $473 \mathrm{~K}$, pressure is $2 \mathrm{MPa}$; *** temperature is $473 \mathrm{~K}$, time is $2 \mathrm{~h}$

To study the effect of optimum parameters on the viscosity index, acid number and ratio $v_{50} / v_{100}$ the mathematical model was built [16]. In this case the regression equations are possible:

$$
\begin{gathered}
y_{1}=b_{1} x_{1}+b_{2} x_{2}+b_{3} x_{3}+b_{12} x_{1} x_{2}+b_{13} x_{1} x_{3}- \\
-b_{23} x_{2} x_{3}+\gamma_{12} x_{1} x_{2}\left(x_{1}-x_{2}\right)+\gamma_{13} x_{1} x_{3}\left(x_{1}-x_{3}\right)+ \\
+\gamma_{23} x_{2} x_{3}\left(x_{2}-x_{3}\right)-b_{123} x_{1} x_{2} x_{3}
\end{gathered}
$$

$$
\begin{gathered}
y_{2}=b_{1} x_{1}+b_{2} x_{2}-b_{3} x_{3}-b_{12} x_{1} x_{2}-b_{13} x_{1} x_{3}- \\
-b_{23} x_{2} x_{3}+\gamma_{12} x_{1} x_{2}\left(x_{1}-x_{2}\right)-\gamma_{13} x_{1} x_{3}\left(x_{1}-x_{3}\right)- \\
-\gamma_{23} x_{2} x_{3}\left(x_{2}-x_{3}\right)+b_{123} x_{1} x_{2} x_{3} \\
y_{3}=-b_{1} x_{1}+b_{2} x_{2}-b_{3} x_{3}-b_{12} x_{1} x_{2}+b_{13} x_{1} x_{3}- \\
-b_{23} x_{2} x_{3}+\gamma_{12} x_{1} x_{2}\left(x_{1}-x_{2}\right)-\gamma_{13} x_{1} x_{3}\left(x_{1}-x_{3}\right)- \\
-\gamma_{23} x_{2} x_{3}\left(x_{2}-x_{3}\right)+b_{123} x_{1} x_{2} x_{3}
\end{gathered}
$$


where parameters of the model are: $x_{1}$ is a process temperature, ${ }^{\circ} \mathrm{C} ; x_{2}$ is time, $\mathrm{h} ; x_{3}$ is pressure, $\mathrm{MPa}$ and response functions are: $y_{1}=v_{50} / v_{100} ; y_{2}$ is viscosity index; $y_{3}$ is acid number, $\mathrm{mg} \mathrm{KOH} / \mathrm{g}$.

When substituting in the equation for $y_{1}$ all values of the parameters $x_{1}, x_{2}$ and $x_{3}$ and the values of $y_{1}$ corresponding to each set of parameters, we obtain a system of equations, the solution of which gives the value of the regression coefficients for the given response function. Similar systems of equations are obtained for other response functions of the mathematical model $\left(y_{2}\right.$ and $y_{3}$ ). When solving each of these systems of equations, we obtain a set of regression coefficients for each response function. To verify the adequacy of the mathematical model, we substitute the parameters values and compare the calculated response functions with the experimental data.

Substituting regression coefficients into regression equations and denoting the model parameters and the response functions by the symbols representing their physical content, we obtain the final form of the mathematical model:

- for $v_{50} / v_{100}$ :

$$
\begin{gathered}
y_{1}=0.00975 x_{1}+0.322 x_{2}+0.00701 x_{3}+0.001607 x_{1} x_{2}+ \\
+0.000250 x_{1} x_{3}-0.301 x_{2} x_{3}+0.00000037 x_{1} x_{2}\left(x_{1}-x_{2}\right)+ \\
+0.00000658 x_{1} x_{3}\left(x_{1}-x_{3}\right)+0.00000457 x_{2} x_{3}\left(x_{2}-x_{3}\right)- \\
\quad-0.000667 x_{1} x_{2} x_{3} \\
\quad \text { for viscosity index: } \\
y_{2}=0.00234 x_{1}+3.245 x_{2}-0.0035 x_{3}-0.0097 x_{1} x_{2}- \\
-0.0559 x_{1} x_{3}-0.0452 x_{2} x_{3}+0.000303 x_{1} x_{2}\left(x_{1}-x_{2}\right)- \\
-0.000507 x_{1} x_{3}\left(x_{1}-x_{3}\right)-0.000451 x_{2} x_{3}\left(x_{2}-x_{3}\right)+ \\
\quad 0.00157 x_{1} x_{2} x_{3} ; \\
\quad \text { for acid number: } \\
\quad y_{3}=-0.0000114 x_{1}+0.393 x_{2}-0.0113 x_{3}- \\
-0.000296 x_{1} x_{2}+0.000450 x_{1} x_{3}-0.0452 x_{2} x_{3}+ \\
+0.00000151 x_{1} x_{2}\left(x_{1}-x_{2}\right)-0.00000167 x_{1} x_{3}\left(x_{1}-x_{3}\right)- \\
\quad-0.0000154 x_{2} x_{3}\left(x_{2}-x_{3}\right)+0.000517 x_{1} x_{2} x_{3} .
\end{gathered}
$$

The obtained regression equations enable to determine the dependence of viscosity index, acid number and ratio $v_{50} / v_{100}$ on the process parameters (pressure, temperature, time) by the calculation method.

According to the data of Table 1 it is established that the thermooxidative regeneration of UMMO for $2 \mathrm{~h}$ at $473 \mathrm{~K}$ and pressure of $2 \mathrm{MPa}$ have a positive effect on the target product. The regenerated mineral oil can serve as a base component for the production of oils, or in other industries. By-products (strippant and residue after vacuum distillation) may be raw material components to produce fuel and bitumen, respectively.

\subsection{Physico-Chemical Properties}

The operational properties of the target and byproducts of UMMO thermooxidative regeneration are given in Tables 3 and 4.

As can be seen from Tables 3 and 4, the oils regenerated via thermooxidative regeneration have better properties than used oils. They are characterized by lower values of acid and base numbers, lower ash content, coking ability and content of mechanical impurities.

Unlike used oil, the regenerated oil does not contain water; its viscosity index is higher. At the same time, the residue after vacuum distillation is characterized by higher values of ash content, coking ability, mechanical impurities content and acid number to compare with regenerated oil.

\subsection{Change in Group Hydrocarbon Composition}

The results of studying the group composition of used oils and fractions obtained during thermooxidative regeneration are shown in Figs. 1 and 2.

Regenerated oils are characterized by a higher content of paraffin-naphthenic hydrocarbons and a lower content of aromatic hydrocarbons as compared with used oils. The amount of paraffin-naphthenic hydrocarbons passed into residue is smaller but the amount of aromatic hydrocarbons is greater.

Table 2

Values of calculated regression coefficients

\begin{tabular}{|c|c|c|c|}
\hline & $v_{50} / v_{100}$ & Viscosity index & Acid number \\
\hline$b_{1}$ & 0.00975 & 0.00234 & 0.0000114 \\
\hline$b_{2}$ & 0.322 & 3.245 & 0.393 \\
\hline$b_{3}$ & 0.00701 & 0.0035 & 0.0113 \\
\hline$b_{12}$ & 0.001607 & 0.0097 & 0.000296 \\
\hline$b_{13}$ & 0.000250 & 0.0559 & 0.000450 \\
\hline$b_{23}$ & 0.301 & 0.0452 & 0.0452 \\
\hline$\gamma_{12}$ & 0.00000037 & 0.000303 & 0.00000151 \\
\hline$\gamma_{13}$ & 0.00000658 & 0.000507 & 0.00000167 \\
\hline$\gamma_{23}$ & 0.00000457 & 0.000451 & 0.0000154 \\
\hline$b_{123}$ & 0.000667 & 0.00157 & 0.000517 \\
\hline
\end{tabular}


Table 3

Operational properties of M-10DM and products after its thermooxidative regeneration

\begin{tabular}{|c|c|c|c|c|}
\hline \multirow{2}{*}{ Index } & \multirow{2}{*}{ UMMO } & \multicolumn{3}{|c|}{ Thermooxidative regeneration } \\
\hline & & Strippant & Regenerated oil & Residue \\
\hline Viscosity, $\mathrm{mm}^{2} / \mathrm{s}$ : & & & & \\
\hline - at $323 \mathrm{~K}, v_{50}$ & 51.65 & 18.15 & 62.05 & 117.18 \\
\hline - at $373 \mathrm{~K}, v_{100}$ & 10.22 & 5.05 & 11.67 & 16.66 \\
\hline$-v_{50} / v_{100}$ & 5.05 & 3.59 & 5.30 & 7.03 \\
\hline Viscosity index & 88 & 102 & 98 & 74 \\
\hline Density, $\mathrm{kg} / \mathrm{m}^{3}$ & 884 & 857 & 863 & 910 \\
\hline Acid number, mg KOH/g & 2.71 & 2.49 & 1.45 & 2.29 \\
\hline Base number, mg KOH/g & 0.35 & 0.23 & 0.18 & 0.12 \\
\hline Water content, $\%$ & 0.14 & - & - & - \\
\hline Mechanical impurities content, \% & 0.062 & traces & 0.015 & 0.198 \\
\hline Coking ability, $\%$ & 2.30 & 0.16 & 1.63 & 6.84 \\
\hline Ash content, $\%$ & 0.940 & 0.001 & 0.022 & 4.21 \\
\hline Freezing point, $\mathrm{K}$ & 254 & 251 & 250 & 259 \\
\hline Flash point, $\mathrm{K}$ & 488 & 471 & 513 & 543 \\
\hline Fraction yield, wt $\%$ & - & 7.23 & 73.50 & 14.77 \\
\hline
\end{tabular}

Table 4

Operational properties of NORMAL $15 \mathrm{~W} 40$ and products after its thermooxidative regeneration

\begin{tabular}{|l|c|c|c|c|}
\hline \multicolumn{1}{|c|}{ Index } & \multirow{2}{*}{ UMMO } & \multicolumn{3}{|c|}{ Thermooxidative regeneration } \\
\cline { 3 - 5 } & & Strippant & Regenerated oil & Residue \\
\hline Viscosity, $\mathrm{mm}^{2} / \mathrm{s}:$ & & & & \\
- at $323 \mathrm{~K}, v_{50}$ & 69.81 & 37.85 & 70.13 & 81.30 \\
- at $373 \mathrm{~K}, v_{100}$ & 13.96 & 8.96 & 14.17 & 13.56 \\
$-v_{50} v_{100}$ & 5.0 & 4.22 & 4.94 & 5.99 \\
\hline Viscosity index & 110 & 115 & 104 & 75 \\
\hline Density, kg/m & 896 & 862 & 895 & 918 \\
\hline Acid number, mg KOH/g & 1.96 & 1.73 & 0.97 & 1.62 \\
\hline Base number, mg KOH/g & 3.46 & 2.87 & 2.27 & 1.89 \\
\hline Water content, \% & 0.15 & - & - & - \\
\hline Mechanical impurities content, \% & 0.039 & traces & 0.012 & 0.165 \\
\hline Coking ability, \% & 1.71 & - & 1.04 & 6.73 \\
\hline Ash content, \% & 0.534 & 0.003 & 0.036 & 1.58 \\
\hline Freezing point, K & 255 & 252 & 253 & 258 \\
\hline Flash point, K & 511 & 478 & 521 & 533 \\
\hline Fraction yield, wt \% & - & 8.38 & 74.25 & 13.37 \\
\hline
\end{tabular}

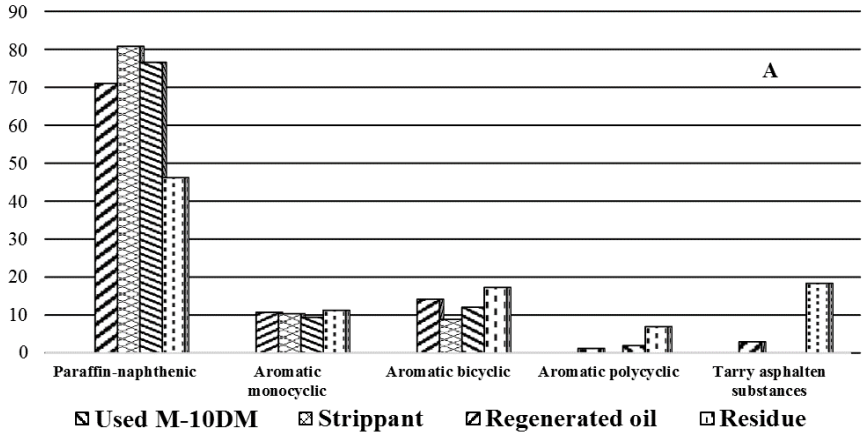

Fig. 1. The group hydrocarbon composition of M-10DM and its products after thermooxidative regeneration

Thus, we can state that regenerated mineral oils which are characterized by the low content of undesirable polycyclic aromatic hydrocarbons and the absence of

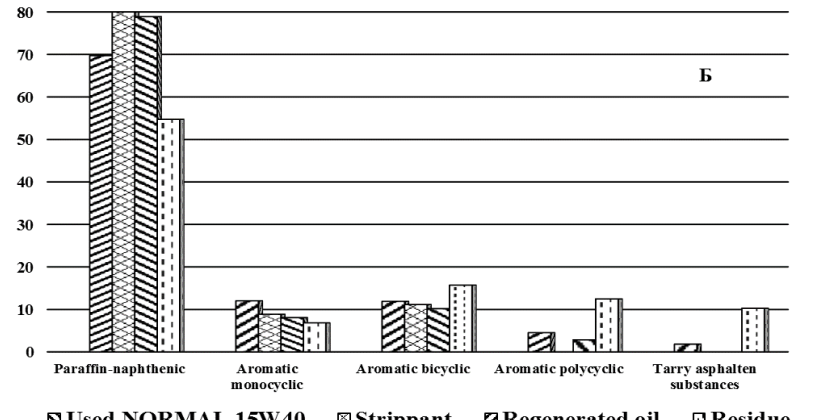

$\triangle$ Used NORMAL 15W40 $₫$ Strippant $\square$ Regenerated oil $\square$ Residue

Fig. 2. The group hydrocarbon composition of NORMAL

$15 \mathrm{~W} 40$ and its products after thermooxidative regeneration

tarry asphaltene substances allows them to be used as components of base oils or as lubricants in various industries. 
XRF analysis of UMMO thermooxidative regeneration

\begin{tabular}{|c|c|c|c|c|}
\hline \multicolumn{5}{|c|}{ Content, ppm } \\
\hline \multirow{2}{*}{ Element } & \multicolumn{2}{|c|}{ M-10DM } & \multicolumn{2}{|c|}{ NORMAL $15 \mathrm{~W} 40$} \\
\hline & in used oil & in residue & in used oil & in residue \\
\hline $\mathrm{Mg}$ & - & - & 549.75 & 2336.44 \\
\hline $\mathrm{Si}$ & - & - & 139.97 & 594.87 \\
\hline $\mathrm{P}$ & 2950.99 & 12541.71 & 2797.05 & 11887.46 \\
\hline $\mathrm{S}$ & 6166.21 & 26206.39 & 6401.21 & 27205.14 \\
\hline $\mathrm{Ca}$ & 16006.38 & 68027.12 & 1445.68 & 6144.14 \\
\hline $\mathrm{Cr}$ & - & - & 52.63 & 223.68 \\
\hline $\mathrm{Mn}$ & 7.09 & 30.13 & 8.8 & 37.40 \\
\hline $\mathrm{Fe}$ & 307.10 & 1305.18 & 696.36 & 2959.53 \\
\hline $\mathrm{Ni}$ & - & - & 5.81 & 24.69 \\
\hline $\mathrm{Cu}$ & - & - & 74.05 & 314.71 \\
\hline $\mathrm{Zn}$ & 4033.07 & 17140.55 & 4360.95 & 18534.04 \\
\hline As & & & 2.99 & 12.71 \\
\hline $\mathrm{Rb}$ & - & - & 1.99 & 8.46 \\
\hline $\mathrm{Zr}$ & 0.17 & 0.72 & - & - \\
\hline $\mathrm{Sr}$ & 4.14 & 17.60 & 2.16 & 9.18 \\
\hline Mo & 1.48 & 6.29 & 48.15 & 204.64 \\
\hline $\mathrm{Pb}$ & 26.90 & 114.33 & 16.11 & 68.47 \\
\hline
\end{tabular}

\subsection{X-Ray Fluorescence Analysis}

The strippant and the basic oil fraction obtained as a result of thermooxidative regeneration are characterized by low ash content and coking ability (Tables 3 and 4). At the same time, the residues after vacuum distillation have much higher values of these indices. Therefore, the next step was to establish the inorganic composition of the residues. The experimental results are given in Table 5.

The obtained regenerated oils are characterized by low ash content and coking ability, indicating the decrease of inorganic components in their composition. At the same time, the products of additives and wear parts decomposition are concentrated in the residue [14].

\subsection{IR Spectroscopy}

To confirm the changes in the group composition of regenerated oils IR spectroscopy was used. The results are shown in Figs. 3 and 4.

As can be seen from Fig. 3, IR spectra of used and regenerated M-10DM differ by the absorption bands. Paraffin-naphthenic hydrocarbons were identified by stretching vibrations at $2935-2915 \mathrm{~cm}^{-1}$, as well as deformation vibrations of $\mathrm{CH}$ group at $1470-1445 \mathrm{~cm}^{-1}$ and stretching vibrations of $\mathrm{C}-\mathrm{C}$ group at $1740-1720 \mathrm{~cm}^{-1}$. The presence of aromatic hydrocarbons in oils was confirmed by an intensive absorption band of $\mathrm{CH}$ group at $860 \mathrm{~cm}^{-1}$. In addition, skeletal vibrations of $\mathrm{C}-\mathrm{C}$ bond of the aromatic nucleus are observed in the region of $1610-1600 \mathrm{~cm}^{-1}$ [15-17].

Oxygen-containing products (alcohols, aldehydes, ketones, organic acids, etc.) were identified in both used and regenerated oils. Their presence is confirmed by the change in absorption bands intensity of $\mathrm{C}=\mathrm{O}$ stretching vibrations in the region of $1740-1690 \mathrm{~cm}^{-1}$, as well as by stretching vibrations at $1820-1740 \mathrm{~cm}^{-1}$ and by asymmetric stretching vibrations of $\mathrm{C}-\mathrm{O}$ bond in the region of $1260-1150 \mathrm{~cm}^{-1}$.

The IR spectra of regenerated NORMAL 15W40 oil (Fig. 5) have a similar relationship.

As can be seen from Fig. 5, infrared spectra of used and regenerated oil NORMAL 15W40 differ by their absorption bands. For regenerated oil we observe the change in the absorption bands typical of oxygen-containing products. It means that the content of oxygen-containing products is decreased. The presence of mentioned products in IR spectra is confirmed by absorption bands of $\mathrm{C}=\mathrm{O}$ stretching vibrations in the region of $1740-1690 \mathrm{~cm}^{-1}$, as well as by stretching vibrations at $1820-1740 \mathrm{~cm}^{-1}$ and asymmetric stretching vibrations of $\mathrm{C}-\mathrm{O}$ bond in the region of $1260-1150 \mathrm{~cm}^{-1}$.

\section{Conclusions}

The optimum parameters of thermooxidative regeneration process of used mineral motor oils (UMMO) were determined: temperature is $473 \mathrm{~K}$, pressure is $2 \mathrm{MPa}$ and process time is $2.0 \mathrm{~h}$. In comparison with used oils the regenerated oils are characterized by higher viscosity index (by 7.2-11.3\%), lower ash content (by 93.3-97.6\%), lower coking ability (by 29.1-39.1\%) and lower acid number (by $46.5-50.5 \%$ ).

The operational properties and the group hydrocarbon composition of M-10DM and NORMAL 15W40 oils, as well as fractions obtained as a result of their thermooxidative regeneration, were studied. The change in the distribution of the hydrocarbon part of used oils in the resulting fractions was established. The results of XRF confirmed that the me- 
tals included in the additives are concentrated in the residue due to UMMO thermooxidative regeneration. The hydro-

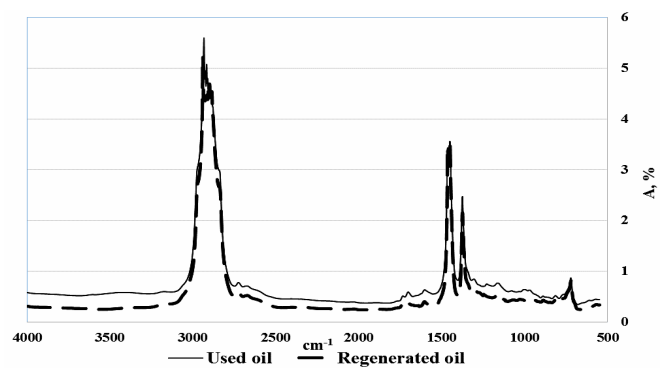

Fig. 3. IR spectra of used and regenerated oil M-10DM

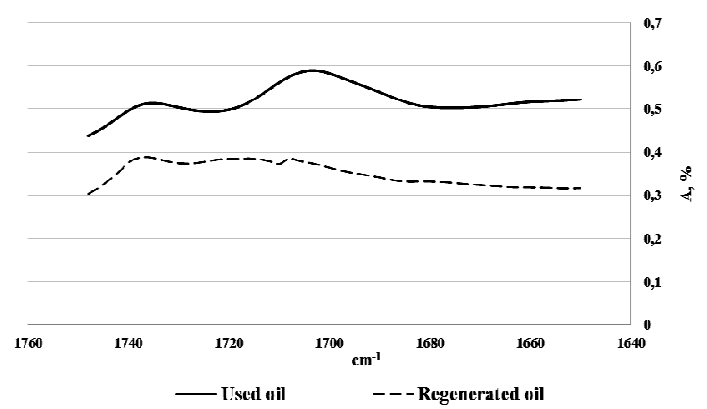

carbon composition and the change in the amount of oxygencontaining products were confirmed by IR spectroscopy.

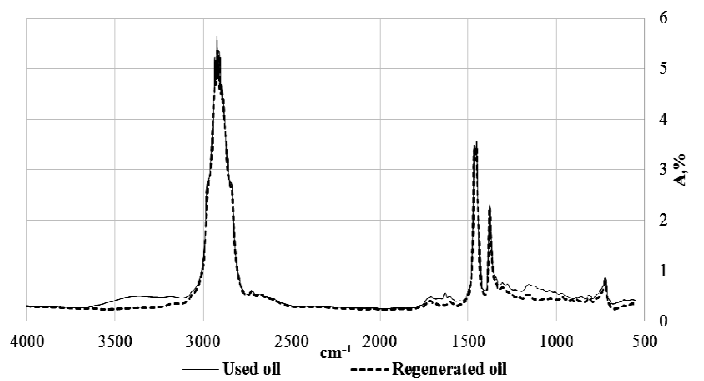

Fig. 5. IR spectra of used and regenerated oil NORMAL $15 \mathrm{~W} 40$

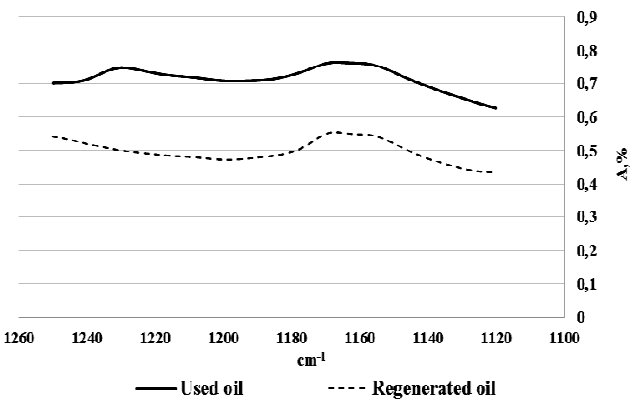

Fig. 4. Changes in the absorption bands intensity of carboxylic acids $(1740-1640 \mathrm{~cm}-1)$ and their derivatives $\left(1250-1110 \mathrm{~cm}^{-1}\right)$ as a result of thermooxidative regeneration of M-10DM

Thermooxidative regeneration has a positive effect on restoring the UMMO operational properties. However, in most cases it cannot be used as an independent process, since regenerated oils require an additional aftertreatment. However, it can serve as an intermediate stage of a certain complex process of regeneration of used mineral motor oils.

\section{References}

[1] Compendium of recycling and destruction technologies for waste oils. United Nations Environment Programme, 2012. https://wedocs.unep.org/bitstream/handle/20.500.11822/8601/IETC Waste Oils Compendium.pdf? [2] Unnisa S. ., Hassanpour M.: Renew. Sust. Energ. Rev., 2017, 72, 605. https://doi.org/10.1016/j.rser.2017.01.109

[3] On Ukraine's Accession to Basel Convention on the Control of Transboundary Movements of Hazardous Wastes and their Disposal. https://zakon.rada.gov.ua/laws/show/ru/995 022

[4] Kulyk M.: Liudyna i Dovkillia, 2015, 1-̄2, 122.

[5] Dalla Giovanna F., Khlebinskaia O., Lodolo A., Miertus S.: Compendium of Used Oil Regeneration Technologies. UNIDO, Trieste 2003

[6] Gaivanovych V., Antonyshyn V., Paniv P.: Pat. Ukr. 37574, Publ. May 15, 2001.

[7] Pysh'yev S., Lazorko O., Bratychak M.: Chem. Chem. Technol., 2009, 3, 1 .

[8] Chervinskyy T., Grynyshyn O., Korchak B.: Naftogazova Galuz Ukrainy, 2016, 2, 32.

[9] Hrynyshyn O., Korchak B., Chervinskyy T., Kochubei V.: Chem. Chem. Technol., 2017, 11, 387.

https://doi.org/10.23939/chcht11.03.387

[10] Korchak B., Hrynyshyn O., Chervinskyy T.: Naukovyi Visnyk NLTU Ukrainy, 2017, 27, 93.
[11] Isaguliants V., Egorova G.: Khimia Nefti. Khimia, Moskva 1965. [12] https://www.environmental-expert.com/products/elvax-modellight-sdd-light-spectrometer-566889

[13] Pinchuk S.: Organizatsia Experimentu pry Modeliuvanni ta Optymizatsii Technichnykh System. Dnipro-VAL, Dnipropetrovsk 2009.

[14] Stout S., Litman E., Blue D.: Environ. Forensics, 2018, 19, 191. https://doi.org/10.1080/15275922.2018.1474288

[15] Garry M.: FT-IR analysis of used lubricating oils - general considerations.

http://www.nicoletcz.cz/upload/kc/files/paliva_maziva/FT-

IR\%20Analysis\%20of\%20Used\%20Lubricating\%20Oils.pdf

[16] Mironov V., Iankovskyy S.: Spectroskopia v Organicheskoi Khimii. Khimia, Moskva 1985.

[17] Tarasevich B: IK Spectry Osnovnykh Klassov Organicheskykh Soedineniy.Khimia, Moskva 2012.

Received: March 26, 2019/Revised: May 15,2019/ Accepted: July 02, 2019

\section{ТЕРМООКИСНЮВАЛЬНА РЕГЕНЕРАЦІЯ ВІДПРАЦЬОВАНИХ МІНЕРАЛЬНИХ МОТОРНИХ ОЛИВ}

Анотація. Вивчено фізико-хімічні властивості та груповий склад відпрачьованих мінеральних моторних олив М-10ДМ та NORMAL 15W40, а також фракиій, одержаних внаслідок їх термоокиснювальної регенерачії. Наведено результати ІЧ-спектроскопічного та рентгенофлуоресцентного аналізу відпраџьованих олив та одержсаних фракиій. Описано зміну складу і властивостей регенерованих олив внаслідок термоокиснювальної регенерації.

Ключові слова: термоокиснювальна регенерачія, відпраиьвована олива, IЧ-спектроскопія, рентгенофлуоресчентний аналіз. 